\title{
MYRACRODRUON URUNDEUVA FR ALL. (AROEIRA TREE) POPULATION DYNAMICS, DIAMETER GROWTH RATE AND ITS POTENTIAL FOR SUSTAINABLE MANAGEMENT IN SUCCESSIONAL TROPICAL DRY FORESTS OF BRAZIL ${ }^{1}$
}

\author{
Sofia Calvo Rodriguez ${ }^{2 *}$, Julio Calvo Alvarado ${ }^{3}$, Mario Marcos do Espírito-Santo $^{4}$, Yule Roberta Ferreira \\ Nunes $^{4}$ \\ ${ }^{1}$ Received on 14.06.2016 accepted for publication on 24.05.2017. \\ ${ }^{2}$ Earth and Atmospheric Sciences Department, University of Alberta, Edmonton, Alberta, Canada. E-mail: <calvorod@ualberta.ca> \\ ${ }^{3}$ School of Forestry, Costa Rican Institute Of Technology,Cartago, Costa Rica. E-mail: <jucalvo@itcr.ac.cr>. \\ ${ }^{4}$ Universidade Estadual de Montes Claros, Doutorado em Ecologia, Montes Claros, Minas Gerais, Brasil. E-mail: $<$ marioesanto@gmail.com> \\ and <yule.rfnunes@gmail.com>. \\ *Corresponding author.
}

\begin{abstract}
Myracrodruon urundeuva, better known in Brazil as "Aroeira", is an arboreal species highly used for its commercial and pharmacological value. Despite the high commercial value in the timber market, this species lacks studies analyzing the recovery time and growth in different stages of succession in the Brazilian tropical dry forests. The main objective of this study was to determine growth rates of this species in three successional stages of a tropical dry forest in Mata Seca State Park, in Minas Gerais, Brazil. We measured all individuals ( $\geq 5 \mathrm{~cm}$ of DBH) annually in 18 permanent plots in early, intermediate, and late successional stages over a period of 8 years (2006-2014). We calculated the annual diameter increments for each individual of this species, for each successional stage and by diameter class. We obtained the following mean annual increments by successional stage: early $(10.53 \mathrm{~mm} / \mathrm{yr})$, intermediate $(2.09 \mathrm{~mm} / \mathrm{yr})$, and late $(2.90 \mathrm{~mm} / \mathrm{yr})$. Increment growth rates were similar between the intermediate and late successional stages. The highest incremental increase in diameter was obtained in the diameter classes $5-15 \mathrm{~cm}$ and $15-25 \mathrm{~cm}$ in the early stage, and for the intermediate stage, maximum increments were found in the $5-15 \mathrm{~cm}$ diameter class and $35-45 \mathrm{~cm}$ class for the late stage. Results from this study support the conclusion that this tree is not only a pioneering species but that it also tolerates the conditions of advanced successional stages. Given the fast and high diametric increments observed in the early stage of succession and the smaller diametric classes, this species demonstrates great potential for silvicultural management.
\end{abstract}

Keywords: Growth rates; Annual diameter increment; Tropical dry forest; Brazil.

\section{Myracrodruon urundeuva Fr All. (AROEIRA) DINAMICA POPULACIONAL, TAXA DE CRESCIMENTO DIAMETRICO E SEU POTENCIAL PARA A MANEJO SUSTENTÁVEL DE FLORESTAS TROPICAIS SECAS SECUNDÁRIAS DO BRASIL}

\begin{abstract}
RESUMO - Myracrodruon urundeuva, mais conhecida no Brasil como "Aroeira", é uma espécie arbórea altamente utilizada por seu valor comercial e farmacológico. Apesar do alto valor comercial no mercado, esta espécie carece de estudos sobre o tempo de recuperação e crescimento em diferentes estágios de sucessão nas florestas secas tropicais brasileiras. O principal objetivo deste estudo foi determinar as taxas de crescimento diamétrico das árvores em três estágios sucessionais da floresta tropical seca no Parque Estadual Mata Seca, em Minas Gerais, Brasil. Nós medimos todos os individuos ( $\geq 5 \mathrm{~cm}$ de DAP) anualmente em 18 parcelas permanentes em estágios sucessionais inicial, intermediário e tardio durante um periodo de 8 anos (2006-2014). Calculamos os incrementos anuais de diâmetro para cada indivíduo desta espécie, para cada estágio sucessional e por classe diamétrica. Foram obtidos os seguintes incrementos médios anuais por estágio sucessional: inicial (10,53 mm/ano), intermediário (2,09 mm/ano) e tardio (2,90 mm/ano). As taxas de incremento foram semelhantes entre os estágios sucessionais intermediário e tardio. O maior aumento incremental de diâmetro foi obtido
\end{abstract}


nas classes de diâmetro $5-15 \mathrm{~cm}$ e $15-25 \mathrm{~cm}$ no estágio inicial, e para o estágio intermediário, incrementos máximos foram encontrados na classe de 5-15 cm de diâmetro e na classe de 35-45 cm no estágio tardio. Os resultados deste estudo permitem concluir que esta árvore não é apenas uma espécie pioneira, mas que também tolera as condições de estágios sucessionais avançados. Tendo em conta os incrementos diametrais rápidos e elevados observados no estágio inicial de sucessão e nas classes de diâmetro menores, esta espécie demonstra grande potencial para o manejo silvicultural.

Palavras-Chave: Taxas de crescimento; Incremento diamétrico anual; Floresta tropical seca; Brasil.

\section{INTRODUCTION}

Myracrodruon urundeuva Allemão (Anarcadiaceae), which is better known in Brazil as the "Aroeira tree", is a xerophytic deciduous tree species (Lorenzi, 1992; Nunes et al., 2008). The "Aroeira tree" is a secondary, pioneer species, which is usually rare in primary forests, but common in disturbed areas (Ferretti et al., 1995). The species has been classified by Linares-Palomino et al., (2011) as a specialist of the tropical dry forests.

The natural distribution of the "Aroeira tree" extends through the Northeast, Southeast, and Midwest regions of Brazil to the Chaco region in Bolivia, Paraguay, andArgentina (Santin and Leitão-Filho, 1991; Lorenzi, 1992; Carvalho, 1994; Gurgel-Garrido et al., 1997; Nunes et al., 2008). In the Andes, this species is found up to 1800 m.a.s.l. (VargasSalazar, 1993; Caetano and Naciri, 2011).

M. urundeuva is a sizeable tree with heights between 20 and 30 meters (Oliveira-Filho et al., 1998). The wood of this species is reddish-brown with a density of 1.00 to $1.21 \mathrm{~g} / \mathrm{cm}^{3}$ (Bertoni and Dickfeldt, 2007). The hardness of the wood makes it economically valuable, and it is widely used in rural areas for construction that requires external resistance and durability, such as sheds, fences, poles, and sleepers (Medina, 1966; Rizzini, 1971, 1995; Nogueira, 1977; Carvalho, 1994; Bertoni and Dickfeldt, 2007). This tree also has pharmacological uses. Its bark has anti-inflammatory, astringent, anti-allergic, and healing properties (Viana et al., 1995; Nunes et al., 2008). The roots are used for treating rheumatism, and the leaves are used to treat ulcers (Almeida et al., 1998; Nunes et al., 2008). Extracts of leaves exhibit strong antioxidant activity and moderated antimicrobial activity (Mota et al., 2015). M. urundeuva wood has also proved to be resistant to microorganisms given the fungicidal and antibacterial properties found in its heartwood (Sá et al., 2009).

Like other species with valuable characteristics and high economic value, $M$. urundeuva has suffered from indiscriminate logging in Brazil, which has compromised their natural populations in some locations to the point where the species has been reported in the past as endangered (Bertoni and Dickfeldt, 2007; Brasil, 2008). The species was considered in the "Brazilian Report on Forest Genetic Resources" in 2012 (FAO, 2012) as a prioritized tree species for genetic conservation and research initiatives in Brazil given its economic value.

In spite of the high commercial value of this species, due to the excellent wood properties and its potential pharmacological use, at present there are no studies analyzing the recovery time and growth of this species in different stages of forest succession in the Brazilian tropical dry forest. This type of analyses can help us understand the value of these forests, improve forest management practices and develop growth models that could help to assess its performance and adaptability for silvicultural management under different environmental conditions.

Previous studies conducted by our research network (TROPI-DRY, Sánchez-Azofeifa et al., 2005a,b; 2013), revealed that the species $M$. urundeuva has a high density of stems and a high rate of diameter growth in the early successional stage (Calvo-Rodriguez et al., 2017a). However, researchers in Brazil, urge more investigations on the dynamics of $M$. urundeuva populations to make inferences about harvest sustainability more accurately (Barros et al., 2016). For this reason, we would like to contribute to the preservation of this species and the tropical dry forest of Brazil, by attempting to demonstrate that this species is a fast-growing valuable tree that has the potential to be harvested in sustainable silvicultural treatments. Consequently, the pressure suffered by the demand on this species could be lessened by obtaining timber and pharmacological products from tree plantations, agroforestry systems or sustainable natural forest management. In the same manner, silvicultural management of this species can enhance the restoration and conservation of tropical dry forest in Brazil. Therefore,

Revista Árvore. 2017;41(3):e410310 
the main objectives of this study were to determine and compare the mortality, recruitment and growth rates in diameter of this species in three successional stages of a tropical dry forest.

\section{MATERIALS AND METHODS}

\section{Study site}

The study was conducted in Mata Seca State Park (MSSP), currently managed by the Forestry State Institute (IEF- Instituto Estadual de Florestas). MSSP has an area of 15,466 hectares at an elevation of 452 m.a.s.1 and is situated in the São Francisco river valley, in Minas Gerais state in Brazil. The exact location is between coordinates $14^{\circ} 48^{\prime} 36^{\prime \prime}-14^{\circ} 56^{\prime} 59^{\prime \prime} \mathrm{S}$ and $043^{\circ} 55^{\prime} 12^{\prime \prime}$ - 04404'12" W (Calvo-Rodríguez, 2017a; Silva et al., 2015). The local climate is considered tropical semiarid (Köppen classification) or tropical dry forest (Holdridge classification). The forest is dominated by deciduous trees that lose almost $90-95 \%$ of their leaf area during the dry season that extends for six months between May and October (Madeira et al., 2009). The average temperature of the study area is $24.4^{\circ} \mathrm{C}$ with a maximum of $32^{\circ} \mathrm{C}$ and a mean annual precipitation of $871 \mathrm{~mm}$ (300-1300mm range), with a rainy season from October to April (Calvo-Rodríguez, 2017b; Silva et al., 2015).

\section{Experimental design}

In MSSP, 18 permanent plots were established in the three successional stages of the forest: early, intermediate, and late ( 6 plots per stage). Each plot has an area of 1.000 $\mathrm{m}^{2}(50 \times 20 \mathrm{~m})$. In each plot, we measured annually the diameters of all individuals of all species with a diameter greater than $5 \mathrm{~cm}$ at breast height $(1.3 \mathrm{~m}$ ) including the species M. urundeuva. Data was collected in the rainy season (between February and Aprill) for each year from 2006 to 2014. Details about the site and successional stages characteristics can be found in Alvarez et al. (2008), Calvo-Rodríguez (2017b), Madeira et al. (2009) and Silva et al. (2015).

Previous studies (Calvo-Rodríguez et al., 2017b) for these plots showed that M.urundeuva (Anacardiaceae) had the greatest ecological weight, with an IVI of 99.06 (Importance Value Index, Curtis and McIntosh, 1951), in the early successional stages. This species had the second highest IVI in the late stage with 31.57 and, although it was not among the most significant in the intermediate forest, it was also present in this stage.

\section{Data analysis}

With the data from each successional stage, we proceeded to calculate for each individual the diameter in millimeters and the basal area per hectare in square meters for 2006 and 2014. Then we calculated the mean annual increment in mm/year (MAI) for M.urundeuva only for those individuals that were present in the measurements between 2006 and 2014. To calculate the MAI for each tree, we divided by 8 (number of years from 2006 to 2014) the incremental difference of the diameters from 2006 to the year 2014. For the statistical comparison of MAI among successional stages, we used the median instead of the arithmetic average, because the data do not have a normal distribution, and the use of the median decreases the bias caused by extreme values (Ortiz and Carrera, 2002; Carvajal-Vanegas and Calvo-Alvarado, 2013a,b). Because of this non-normal distribution, we used the KruskalWallis non-parametric statistical test (Kruskal and Wallis, 1952).

Tree mortality $(m)$, recruitment $(r)$, were calculated using a logarithmic model (Lieberman and Lieberman, 1987; Sheil et al., 1995; Condit et al., 1999; CarvajalVanegas and Calvo-Alvarado, 2013a,b). The mortality and the recruitment in each successional stage were calculated using the following formulas:

$$
\begin{gathered}
m=\frac{\ln N_{06}-\ln N_{\mathrm{s}}}{T} \\
r=\frac{\ln N_{14}-\ln N_{\mathrm{s}}}{T}
\end{gathered}
$$

EQ2.

EQ1.

where $N_{06}$ is the number of individuals present in 2006, $N_{\mathrm{S}}$ is the number of individuals surviving in 2014, and for recruitment, $N_{14}$ is the number of individuals surviving in 2014 plus the number of individuals recruited during the time period $T$.

\section{RESULTS}

We tallied 108 individuals of this species within the 18 plots in 2006 and 271 individuals in 2014 (Table 1). Mortality rates were higher in the early and intermediate stage $(7.4 \%$ and $8.2 \%$ respectively) and recruitment rates were higher in the early stage $(22.9 \%)$.

In total, 97 trees were chosen within the 18 plots for the analysis of growth among the three successional stages. The largest MAI was in the early stage (10.53 \pm 3.77 $\mathrm{mm} /$ year, $\mathrm{n}=62)$, which was significantly different $(\mathrm{p}<0.05)$ 
Table 1 - Average density of individuals, basal area, recruitment, and mortality per hectare for Myracrodruon urundeuva in three successional stages at MSSP, Brazil during 2006 to 2014.

Tabela 1 - Densidade média de indivíduos, área basal, recrutamento e mortalidade por hectare de Myracrodruon urundeuva em três estágios sucessionais no MSSP, Brasil, entre 2006 e 2014.

\begin{tabular}{|c|c|c|c|c|c|c|c|c|}
\hline \multirow[b]{2}{*}{ Stage } & \multicolumn{2}{|c|}{ Year 2006} & \multicolumn{2}{|c|}{ Year 2014} & \multicolumn{2}{|c|}{ Recruitment } & \multicolumn{2}{|c|}{ Mortality } \\
\hline & $\begin{array}{l}\text { Density } \\
\left(\mathrm{n} \mathrm{ha}^{-1}\right)\end{array}$ & $\begin{array}{c}\text { Basal area } \\
\left(\mathrm{m} 2 \mathrm{ha}^{-1}\right)\end{array}$ & $\begin{array}{l}\text { Density } \\
\left(\mathrm{n} \mathrm{ha}^{-1}\right)\end{array}$ & $\begin{array}{c}\text { Basal area } \\
\left(\mathrm{m} 2 \mathrm{ha}^{-1}\right)\end{array}$ & $\begin{array}{l}\text { Density } \\
\left(\mathrm{n} \mathrm{ha}^{-1}\right)\end{array}$ & $\%$ total & $\begin{array}{l}\text { Density } \\
\left(\mathrm{n} \mathrm{ha}^{-1}\right)\end{array}$ & $\%$ total \\
\hline Early & 112.0 & 0.5 & 388.0 & 3.8 & 316.0 & 22.9 & 50.0 & 7.4 \\
\hline Intermediate & 25.0 & 2.0 & 20.0 & 1.6 & 0.0 & 5.4 & 12.0 & 8.2 \\
\hline Late & 58.0 & 4.7 & 56.0 & 5.2 & 15.0 & 2.7 & 13.0 & 3.2 \\
\hline Total & 195.0 & 7.2 & 464.0 & 10.5 & 331.0 & 31.0 & 75.0 & $\overline{18.8}$ \\
\hline
\end{tabular}

from the intermediate and late stages. Among the intermediate $(2.09 \pm 1.54 \mathrm{~mm} /$ year, $\mathrm{n}=8)$ and late stages $(2.90 \pm 2.86 \mathrm{~mm} /$ year, $\mathrm{n}=32)$, no significant difference was found $(\mathrm{p}=0.05)$.

This species attained a maximum increment of 17.91 $\mathrm{mm} /$ year in the early stage, while in the intermediate and late stages it only reached maximum increments of $4.38 \mathrm{~mm} /$ year and $9.30 \mathrm{~mm} /$ year, respectively. Most of our measurements of MAI were between 2-14 mm per year (Figure 1). The median of the total population was $8.15 \mathrm{~mm} /$ year for all forest successional stages. The species is found in all diameter classes from 5 $\mathrm{cm}-65 \mathrm{~cm}$ (Figure 2), but maximum increments were obtained in the diameter classes 5-15 cm and 15-25 $\mathrm{cm}$ in the early stage. For the intermediate stage, maximum increments were found in the $5-15 \mathrm{~cm}$ diameter class and, for the late stage, in the $35-45 \mathrm{~cm}$ class.

\section{DISCUSSION}

Recruitment and mortality rates were higher in the early and intermediate stages than in the late stage of succession. It is expected that at lower diameter classes, there is intense competition for space and resources, because of the wide variety of species and individuals that seek to establish themselves in this ecosystem (Monge et al., 2002). Also, the results strongly suggest that $M$. urundeuva has its most rapid diameter growth rate within the early successional stage. According to Vieira et al., (2007), this species grows more rapidly where there is more light exposure than it does in forests with less disturbance.

In the early successional stage, $M$. urundeuva has a rapid incremental growth in diameter $(\mathrm{MAI}=10.53$

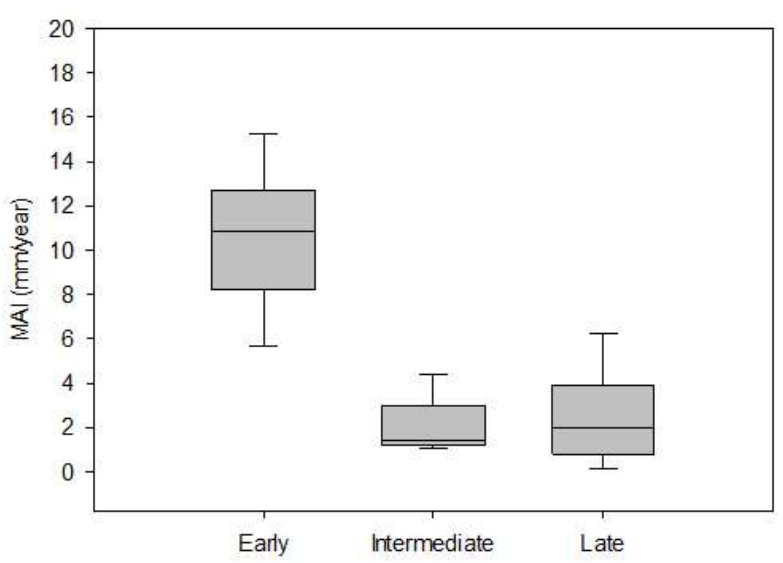

Figure 1 - Distribution of the mean diameter annual increments (MAI, as median in $\mathrm{mm} /$ year) and minimum and maximum values observed for Myracrodruon urundeuva in three successional stages in Mata Seca State Park, Minas Gerais Brazil.

Figura 1 -Distribuição de média de incrementos anuais (MAI, como mediana em mm/ano) e valores mínimos e máximos observados para Myracrodruon urundeuva em três estádios sucessionais no Parque Estadual Mata Seca, Minas Gerais Brasil.

$\mathrm{mm} /$ year), indicating that in this stage the species could reach diameters of $12-20 \mathrm{~cm}$ in $10-15$ years. This diameter range is very acceptable for harvesting trees for rural use, for non-wood forest products and for the small diameter wood industry (Keegan et al., 2004; BermúdezCruz et al., 2006). Our results are comparable with those obtained by Bertoni and Dickfeldt, (2007) in Brazil, who showed that this species was effective in restoring a disturbed area, by obtaining a diameter of $8.25 \mathrm{~cm}$, a height of $7.20 \mathrm{~m}$, and a survival rate of $90 \%$ over ten years.

In the intermediate and late successional stages, the MAIs are very slow, which is normal for a species with a high wood density, and hence it will take several years to reach larger diameters. Venturoli et al., (2015)

Revista Árvore. 2017;41(3):e410310 


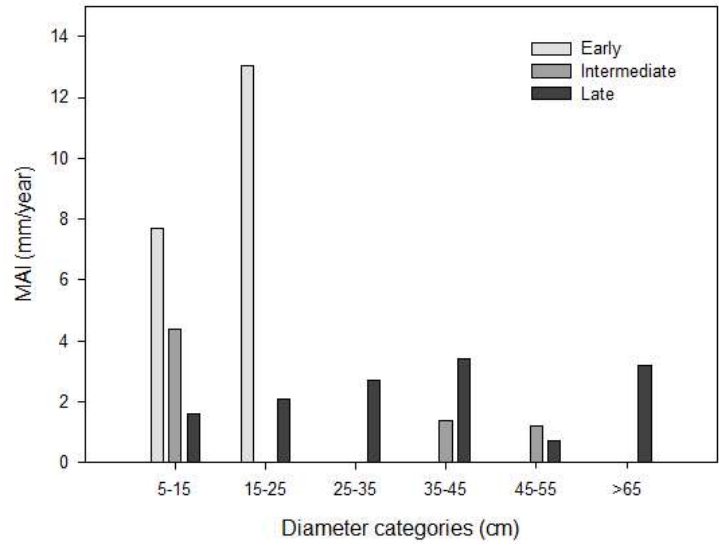

Figure 2 - Mean annual increments for Myracrodruon urundeuva for each diameter class in MSSP, Minas Gerais, Brazil.

Figura 2-A média de incrementos anuais de Myracrodruon urundeuva para cada classe de diâmetro em MSPS, Minas Gerais, Brasil.

found annual increments of 1.4 to 3.3 (mm/year) for this species in a semideciduous secondary forest in Goiás, Brazil. In this study, they analyzed annual increments of species with the highest importance value index, under treatments such as removal of all woody individuals within a radius of one meter from the desirable trees, removal of all large lianas in the plot and, introduction of seedlings. Greatest increments of $M$. urundeuva were observed in the plots where the three treatments were applied (Venturoli et al., 2015), showing that this species responded positively to silvicultural interventions.

Although this species grows in secondary forests, its rate of growth is also comparable to commercial species established in plantations, where growth is optimized, and there is even a genetic selection. For example, our results compare very well with MAIs reported for Teak plantations at several sites across Central America. Specifically, for sites with the same climatic conditions (Tropical dry forest, Life Zone) as in our study where MAIs were reported, growth rates in three different teak plantations in Panama were 10 - $15 \mathrm{~mm} /$ year (Chaves and Fonseca, 1991). The MAIs of $M$. urundeuva in natural forest are even higher than the increments of other valuable tropical tree species for the dry forest, such as mahogany (Swietenia macrophylla King). Grogan, (2001) found in southern Pará (Brazil) MAIs between $4.9 \mathrm{~mm} /$ year and $7.9 \mathrm{~mm} /$ year for mahogany trees with DBH greater than $10 \mathrm{~cm}$.
While in Quintana Roo, Mexico, Negreros-Castillo and Mize (2014) found for mahogany trees with a DBH $\geq$ $10.0 \mathrm{~cm}$ MAIs of $2.2 \mathrm{~mm} / \mathrm{yr}$ on average and maximum MAIs of $19.7 \mathrm{~mm} / \mathrm{yr}$.

\section{CONCLUSION}

Results from this study support the conclusion that this tree is not only a pioneering species, but that it also tolerates the conditions of advanced successional stages. Highest diametric increments were observed in the early stage of succession and in the smaller diametric classes. Intermediate and late succession plots also had considerable diametric increments, however, these were significantly lower than the early stage. Because of its excellent wood properties, its pharmacological potential, the high tree density, and high diameter growth rates found in this study, especially in the early successional stage, we also conclude that the "Aroeira tree" should be studied to become a flag species for silvicultural management of the tropical dry forest of Brazil and to be a domesticated tree for agroforestry and forest plantations systems.

\section{ACKNOWLEDGEMENTS}

This work is part of the Research Project: TROPIDRY (Human, Ecological and Biophysical Dimension on Tropical Dry Forest) a collaborative research network funded by the Inter American Institute for Global Change Research (IAI) Collaborative Research Network Program (CRN2021), supported by the U.S. National Science Foundation (Grant GEO 0452325). We also received support from the Costa Rican Institute of Technology (ITCR), University of Alberta, Fundação de Amparo à Pesquisa de Minas Gerais (FAPEMIG) and Conselho Nacional de Desenvolvimento Científico e Tecnológico (CNPq).

\section{REFERENCES}

Almeida SPD. Cerrado. Planaltina, DF: Empresa Brasileira de Pesquisa Agropecuaìria, Centro de Pesquisa Agropecuaìria dos Cerrados, Ministério da Agricultura e do Abastecimento; 1998.

Alvarez M, Avila-Cabadilla LD, Berbara R, CalvoAlvarado JC, Cuevas-Reyes P, Espírito-Santo MM et al. Ecology procedures. In: Nassar JM, Rodríguez JP, Sánchez-Azofeifa GA, Garvin T, Quesada M editores Manual of methods: human, ecological and biophysical dimensions of tropical 
dry forests. Caracas: Instituto Venezolano de Investigaciones Científicas; 2008. p.15-46.

Barros FN, Nascimento VT, Medeiros PM. Ethnobotany and population status of Myracrodruon urundeuva Allemão in rural northeastern Brazil. Economic Botany. 2016;70:79-84.

Bermúdez-Cruz GE, Serrano R, Rodríguez Varela I. Proceso de aserrío de trozas de diámetros menores de Gmelina arborea Roxb., para la producción de madera para la construcción. Revista Forestal Mesoamericana Kurú. 2006;3:27-40.

Bertoni JE, Dickfeldt EP. Plantio de Myracrodruon urundeuva Fr. All. (Aroeira) em área alterada de floresta: desenvolvimento das mudas e restauração florestal. Revista do Instituto Florestal. 2007;19:31-8.

Brasil. Leis e decretos. Instrução Normativa, de 23 de setembro de 2008. Lista as espécies da flora brasileira ameaçadas de extinção. Diário Oficial da União, Brasília, Edição 185, p. 75-83, 2008.

Caetano S, Naciri Y. The biogeography of seasonally dry tropical forests in South America. In: Dirzo R, Young H, Mooney H, Ceballos G editors. Seasonally dry tropical forests. London: Ecology and Conservation Island Press2011. p.2344.

Calvo-Rodriguez S, Calvo-Alvarado JC, EspíritoSanto MM, Nunes YR. Tree diameter growth for three successional stages of Tropical Dry Forest in Minas Gerais, Brazil. Revista Forestal Mesoamericana Kurú. 2017a;14(35):24-32.

Calvo-Rodriguez S, Calvo-Alvarado JC, EspíritoSanto MM, Nunes YR. Changes in forest structure and composition in a successional tropical dry forest. Revista Forestal Mesoamericana Kurú. 2017b;14(35):12-23.

Carvajal-Vanegas D, Calvo-Alvarado JC. Tree diameter growth of three successional stages of tropical dry forests, Santa Rosa National Park, Costa Rica. In: Sánchez-Azofeifa GA, Powers JS, Fernandes GW, Quesada M editors. Tropical dry forests in the Americas: ecology, conservation and management. Boca Raton: CRC Press, 2013a. p.281-99.

Carvajal-Vanegas D, Calvo-Alvarado JC. Tasas de crecimiento, mortalidad y reclutamiento de vegetación en tres estadios sucesionales del bosque seco tropical, Parque Nacional Santa Rosa, Costa Rica. Revista Forestal Mesoamericana Kurú. 2013b;10:1-12.

Carvalho PER. Espécies florestais brasileiras: recomendações silviculturais, potencialidades e uso da madeira. Brasília, D.F.: Embrapa-CNPF/SPI; 1994.

Chaves E, Fonseca W. Teca (Tectona grandis L.f.) especie de árbol de uso multiple en América Central. Turrialba: CATIE/ROCAP; 1991. p.26-35.

Condit R, Ashton PS, Manokaran N, Lafrankie JV, Hubbell SP, Foster RB. Dynamics of the forest communities at Pasoh and Barro Colorado: comparing two 50-ha plots. Philosophical Transactions of the Royal Society B: Biological Sciences. 1999;354(1391):1739-48.

Curtis JT, Mcintosh RP. An upland forest continuum in the prairie-forest border region of Wisconsin. Ecology. 1951;32(3):476-96.

FAO. The state of the world forest genetic resources: country report, Brazil. Brazilian Report on Forest Genetic Resources; First National Report; 2012.

Ferretti AR, Kageyama PY, Árboez GF, Santos JD, Barros MIA, Lorza RF et al. Classificação das espécies arbóreas em grupos ecológicos para revegetação com nativas no estado de São Paulo. Florestar Estatístico. 1995;3(7);73-7.

Grogan JE. Big leaf mahogany (Swietenia macrophylla King) in southeast Pará, Brazil: a life history study with management guidelines for sustained production from natural forests [thesis]. New Haven: Yale University School of Forestry \& Environmental Studies; 2001.

Gurgel-Garrido LMA, Cruz SF, Faria HH, Garrido MAO, Vilas Boas O. Efeitos do sombreamento no crescimento da aroeira Myracrodruon urundeuva Fr. All. Revista do Instituto Florestal. 1997;9:47-56.

Keegan CE, Morgan TA, Wagner FG, Spoelma TP, Cohn PJ, Blatner KA. et al. Timber use, processing capacity, and capability to utilize small-diameter timber within USDA Forest Service, Region One 
timber-processing area. Missoula: Bur. Business and Economic Research, University of Montana; 2004.

Kruskal WH, Wallis WA. Use of ranks in one-criterion variance analysis. Journal of the American Statistical Association. 1952;47(260):583-621.

Lieberman D, Lieberman M. Forest tree growth and dynamics at La Selva, Costa Rica (1969-1982). Journal of Tropical Ecology. 1987;3(4):347.

Linares-Palomino R, Oliveira-Filho AT, Pennington RT. Neotropical seasonally dry forests: diversity, endemism, and biogeography of woody plants. In: Dirzo R, Young H, Mooney H, Ceballos G editors. Seasonally dry tropical forests: ecology and conservation. London: Island Press; 2011. p.3-21.

Lorenzi H. Árvores brasileiras: manual de identificação e cultivo de plantas arbóreas nativas do Brasil. Nova Odessa: Plantarum; 1992.

Madeira B, Espírito-Santo MM, Sanz D’angelo V, Nunes YRF, Sánchez-Azofeifa A, Fernandes W et al. Changes in tree and liana communities along a successional gradient in a tropical dry forest in southeastern Brazil. Plant Ecology. 2009;201:291-304.

Medina JC. Flora do Brasil - dicotiledôneas arbóreas úteis. Campinas: Instituto Agronômico de Campinas; 1966.

Monge A, Quesada R, Gonzalez E. Estudio de la dinamica del bosque seco tropical a partir de parcelas permanentes de muestreo en el parque nacional Palo Verde, Bagaces, Costa Rica. In: Chaverri A, Quesada R, Chaves E, Fonseca W, Sanabria E editors Ecosistemas forestales de bosque seco tropical: investigaciones y resultados en Mesoamerica. Heredia, Costa Rica: Universidad Nacional / INISEFOR; 2002. p.175-84.

Mota BCF, De Andrade Royo V, Fonseca JMS, Dos Santos AC, De Melo Júnior AF, Menezes EV et al. Comparative studies between the chemical constituents and biological properties of the extracts from the leaves and barks of Myracrodruon urundeuva Fr. All. Journal of Medicinal Plants Research. 2015;9(6):159-68.

Negreros-Castillo P, Mize CW. Mahogany growth and mortality and the relation of growth to site characteristics in a natural forest in Quintana Roo,
Mexico. Forest Science. 2014;60(5):907-13.

Nogueira JCB. Reflorestamento heterogêneo com essências indígenas. São Paulo: Instituto Florestal; 1977.

Nunes YRF, Fagundes M, Almeida HDS, Veloso MDDM. Aspectos ecológicos da aroeira (Myracrodruon urundeuva Allemão- Anacardiaceae): fenologia e germinação de sementes. Revista Árvore. 2008;32(2):233-43.

Oliveira-Filho AT, Curi N, Vilela EA, Carvalho DA. Effects of canopy gaps, topography, and soils on the distribution of woody species in a central brazilian deciduous dry forest. Biotropica. 1998;30(3):362-75.

Ortiz E, Carrera F. Estadística básica para inventarios forestales. In: Orozco L, Brumér C editors. Inventarios forestales para bosques latifoliados en América Central. Turrialba: CATIE; 2002. p.71-99.

Rizzini CT. Árvores e madeiras úteis do Brasil: manual de dendrologia brasileira. São Paulo: Edgard Blucher; 1971.

Rizzini CT. Árvores e madeiras úteis do Brasil: manual de dendrologia brasileira. $2^{\mathrm{a}}$. ed. São Paulo: Edgard Blucher; 1995.

Sá RA, Gomes FS, Napoleão TH, Santos ND, Melo CM, Gusmão NB et al. Antibacterial and antifungal activities of Myracrodruon urundeuva heartwood. Wood Science and Technology. 2009;43(12):85-95.

Sánchez-Azofeifa GA, Calvo-Alvarado JC, EspiritoSanto MM, Fernandes G, Powers J, Quesada M. Tropical dry forest in the Americas: the tropi-dry endeavour. In: Sánchez-Azofeifa GA, Powers J, Fernandes G, Quesada M editors. Tropical dry forests in the Americas: Ecology, conservation and management. Boca Raton: CRC Press, 2013. p.1-16.

Sánchez-Azofeifa GA, Kalacska M, Quesada M, Calvo-Alvarado JC, Nassar J, Rodríguez J. Need for integrated research for a sustainable future in tropical dry forests. Conservation Biology. 2005a;19:1-2.

Sánchez-Azofeifa GA, Quesada M, Rodríguez P, Nassar J, Stoner K, Castillo A et al. Research priorities for neotropical dry forests. Biotropica. 
2005b;37(4):477-85.

Santin DA, Leitão FH. Restabelecimento e revisão taxonômica do gênero Myracrodruon Freire Allemão (Anacardiaceae). Brazilian Journal of Botany. 1991;14(2):133-45.

Sheil D, Burslem DFRPY, Alder D. The Interpretation and Misinterpretation of Mortality Rate Measures. The Journal of Ecology. 1995;83(2):331.

Silva JO, Espírito-Santo MM, Morais HC. Leaf traits and herbivory on deciduous and evergreen trees in a tropical dry forest. Basic and Applied Ecology. 2015;16:210-9.

Vargas-Salazar E. Anacardiaceae. In: Killeen T, Garcia
E, Beck S editors. Guía de Arboles de Bolivia. La Paz: Herbario Nacional de Bolivia, Missouri Botanical Garden; 1993. p.93-7.

Venturoli F, Franco AC, Fagg CW. Tree diameter growth following silvicultural treatments in a semideciduous secondary forest in central Brazil. Cerne. 2015;21(1):117-23.

Viana GSB, Matos FJA, Bandeira MAM, Rao VSN. Aroeira-do-sertão: estudo botânico, farmacognóstico, químico e farmacológico. Fortaleza: Edicões UFC; 1995.

Vieira DLM, Scariot A, Holl KD. Effects of habitat, cattle grazing and selective logging on seedling survival and growth in dry forests of central Brazil. Biotropica. 2007;39(2):269-74.

Revista Árvore. 2017;41(3):e410310 